\title{
RANCANG BANGUN E-LEARNING BAHASA INGGRIS PADA SMP ISLAM TERPADU INSAN MANDIRI KOTA SUKABUMI
}

\author{
Tya Septiani Nurfauzia Koeswara ${ }^{1}$, Yusti Farlina ${ }^{2}$,Desi Susilawati ${ }^{3}, E$ Elah Nurlelah ${ }^{4}$ \\ 1 Universitas Bina Sarana Informatika \\ e-mail: tya.tsf@bsi.ac.id, yusti.yfa@bsi.ac.id, desi.dlu@bsi.ac.id, elah.enl@bsi.ac.id
}

\begin{abstract}
Proses pembelajaran di era perkembangan teknologi saat ini memungkinkan ketidakhadirannya guru didalam kelas, siswa dapat belajar dimana saja dan kapan saja tanpa harus melakukan komunikasi verbal dengan guru. Dengan adanya fasilitas internet, sistem pembelajaran dibuat online atau sering disebut e-learning yang akan memudahkan siswa dalam memperoleh materi pembelajaran. SMP Islam Terpadu Insan Mandiri masih menggunakan metode konvensional dalam sistem pembelajarannya, khususnya dalam pelajaran Bahasa Inggris, sehingga interaksi cenderung berjalan satu arah dan kurangnya keaktifan siswa dalam belajar. Untuk itu dibuatlah sebuah perancangan E-learning mata pelajaran Bahasa Inggris khususnya untuk siswa kelas VII sebagai sistem pembelajaran dengan inovasi baru dengan harapan siswa dapat lebih aktif lagi dalam belajar.
\end{abstract}

\section{Kata Kunci: Rancang Bangun, E-learning, Bahasa Inggris}

\section{Pendahuluan}

Pendidikan harus mendapat prioritas untuk meningkatkan kualitas sumber daya manusia demi mempersiapkan daya saing bangsa dalam segala bidang, termasuk didalamnya pendidikan Bahasa Inggris. (Astika, 2015:88). Berdasarkan Peraturan Pemerintah No. 19 tentang Standar Nasional Pendidikan tahun 2012 Pasal 19 Ayat 1, dalam proses pembelajaran pada satuan pendidikan diselenggarakan secara interaktif, inspiratif, menyenangkan, memotivasi siswa untuk berpartisipasi aktif, memberikan ruang gerak yang cukup bagi prakarsa, kreativitas dan kemandirian sesuai dengan bakat, minat dan perkembangan fisik dan psikologis siswa (Peraturan Pemerintah dalam Yadzi, 2012).

E-learning merupakan model pembelajaran yang memanfaatkan fasilitas teknologi informasi dan komunikasi. Dengan teknologi informasi ini dapat berperan sebagai media yang menyediakan antara siswa dan pengajar, sumber belajar dan sarana untuk mengefesiensikan evaluasi pembelajaran (Sriwihajriyah dkk, 2012:451).

SMP Islam Terpadu Insan Mandiri Kota Sukabumi merupakan lembaga pendidikan formal yang setara dengan sekolah menengah pertama yang pengelolaannya dilakukan oleh Yayasan Insan Mandiri dimana proses pembelajarannya masih bersifat konvensional (Junaedi, 2016). Dengan kata lain, proses belajar mengajar antar siswa dengan guru masih didalam kelas dengan bertatap muka langsung. Jika pertemuan antara siswa dengan guru tidak terjadi, secara otomatis proses pembelajaran pun tidak dapat dilaksanakan.

Selain itu proses transfer ilmu pengetahuan hampir sepenuhnya dilakukan di dalam kelas yang menyebabkan transfer ilmu pengetahuan bisa terlambat jika pertemuan tidak terjadi. Keadaan seperti ini sangat jelas dapat menghambat proses pembelajaran yang dapat berakibat berkurangnya pemahaman siswa terhadap suatu materi pembelajaran, khususnya pelajaran Bahasa Inggris (Nurhayati, 2016).

Maka dibuatlah sistem pembelajaran online (e-learning) yang digunakan sebagai sarana untuk proses belajar mengajar yang dilaksanakan tanpa harus bertatap muka secara langsung antara guru dengan siswa (Ardiansyah, 2013).

E-learning juga sebagai salah satu metode pembelajaran jarak jauh, dapat digunakan untuk mengadaptasi kebutuhan-kebutuhan pembelajaran yang 
mendukung pembelajaran konvensional. (Winarno, 2013).

\section{Metode Penelitian}

\subsection{Teknik Pengumpulan Data}

Untuk memperoleh data yang akurat dalam penulisan skripsi ini, maka digunakan tiga metode sebagai sarana untuk membantu dan memudahkan dalam penyusunan laporan, yaitu:

a. Observasi

Metode ini dilakukan dengan cara mengunjungi langsung SMP Islam Terpadu Insan Mandiri Kota Sukabumi dan melakukan pengamatan-pengamatan terhadap sistem pembelajaran di sekolah tersebut, sehingga dapat diperoleh data yang tepat dan akurat.

b. Wawancara

Untuk mendapatkan informasi secara lengkap, dilakukan metode tanya jawab dengan Kepala Sekolah dan Guru mata pelajaran mengenai sistem pembelajaran di SMP Islam Terpadu Insan Mandiri Kota Sukabumi, khususnya pelajaran Bahasa Inggris.

c. Studi Pustaka

Dilakukan dengan cara mencari informasi dari berbagai literature, bukubuku, jurnal ilmiah, website yang berhubungan dengan sistem pembelajaran online (e-learning) di SMP Islam Terpadu Insan Mandiri Kota Sukabumi.

\subsection{Model Pengembangan Sistem}

\section{A. Analisa Kebutuhan Sistem}

Analisa kebutuhan sistem dimulai dari pengumpulan data dari pihak sekolah selengkap mungkin dengan cara mewawancarai narasumber mengenai gambaran umum dalam proses belajar mengajar yang selama ini diterapkan. Menelaah hasil yang dicapai dari penerapan cara belajar Bahasa Inggris yang masih bersifat konvensional, tanpa adanya peralatan pendukung dan identifikasi kebutuhan perangkat keras dan perangkat lunak. Kebutuhan sistem secara global mulai dari pendefinisian sistem proses, fitur program, perancangan database hingga pemakaian aplikasi.

\section{B. Desain}

Pada tahap ini dilakukan identifikasi desain perancangan fungsional program dari sisi pemakai dan tampilan dengan rancangan usecase sebagai alat bantu untuk pemodelan sistem.

\section{Code Generation}

Pada tahap ini dilakukan penulisan kode program menggunakan PHP dengan database MySQL yang dijalankan pada server xammp sesuai fungsi dari program itu sendiri.

\section{Testing}

Pengujian bertujuan untuk menemukan kemungkinan kesalahan yang ada pada aplikasi e-learning dengan menggunakan black box testing, meliputi pengecekan input dan hasil output agar sesuai dengan yang diharapkan.

\section{E. Support}

Support system dalam pembuatan program ini adalah spesifikasi hardware dan software serta melakukan pemeliharaan dan upgrade tool system. Penerapan program merupakan tahap dimana peneliti menjalankan program yang telah dibuat dan diuji kedalam lingkungan sekolah dengan hardware dan software yang memadai.

\section{Hasil dan Pembahasan}

A. Proses Bisnis Sistem

Proses belajar mengajar di SMP Islam Terpadu Insan Mandiri Kota Sukabumi yang sekarang berjalan yaitu dengan bertatap muka langsung, setiap siswa berada dalam satu ruangan kelas, dimana guru akan memberikan materi pelajaran dengan metode ceramah.

Untuk pelajaran Bahasa Inggris, setiap jam pelajarannya guru akan menyampaikan materi kepada siswa secara langsung, kemudian memberikan latihan atau mengadakan dialog Bahasa Inggris sesuai dengan materi pembahasan. Diakhir pertemuan biasanya guru membeikan kesempatan kepada siswa untuk bertanya sesuai materi yang sudah disampaikan atau mengenai pembelajaran Bahasa Inggris yang kurang dipahamin oleh siswa.

Proses pembelajaran Bahasa Inggris saat ini, guru tidak menggunakan media pendukung lain, seperti audio, video ataupun gambar yang dapat membantu siswa untuk lebih tertarik dalam memahami pelajaran.

\section{B. Tahap Analisa}


Analisa kebutuhan software untuk $e$ learning, dimana proses pembelajaran dilakukan tanpa bertatap muka secara langsung antara siswa dan guru.

Berikut ini kebutuhan (system requirement) dari sistem e-learning:

Halaman Siswa:

A.1. Siswa dapat melihat profil sekolah

A.2. Siswa melakukan login

A.3. Siswa mengunduh materi pelajaran

A.4. Siswa mengerjakan soal latihan

Halaman Guru:

B.1. Guru melakukan login

B.2. Guru dapat mengunggah materi

B.3. Guru dapat mengunggah soal latihan

B.4. Guru dapat melihat nilai siswa

Halaman Admin:

C.1. Admin melakukan login

C.2. Admin dapat mengelola data guru

C.3. Admin dapat mengelola data siswa

C.4. Admin dapat mengelola data administrator

\section{Use case Diagram}

1. Use case Diagram Belajar Online

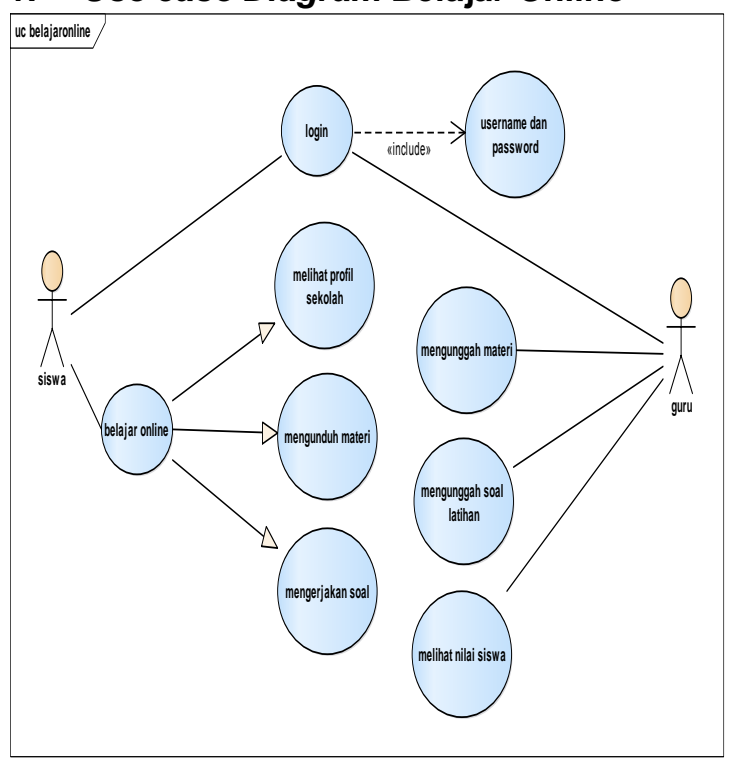

Gambar 1. Use case Diagram Belajar Online
2. Use case Diagram Admin

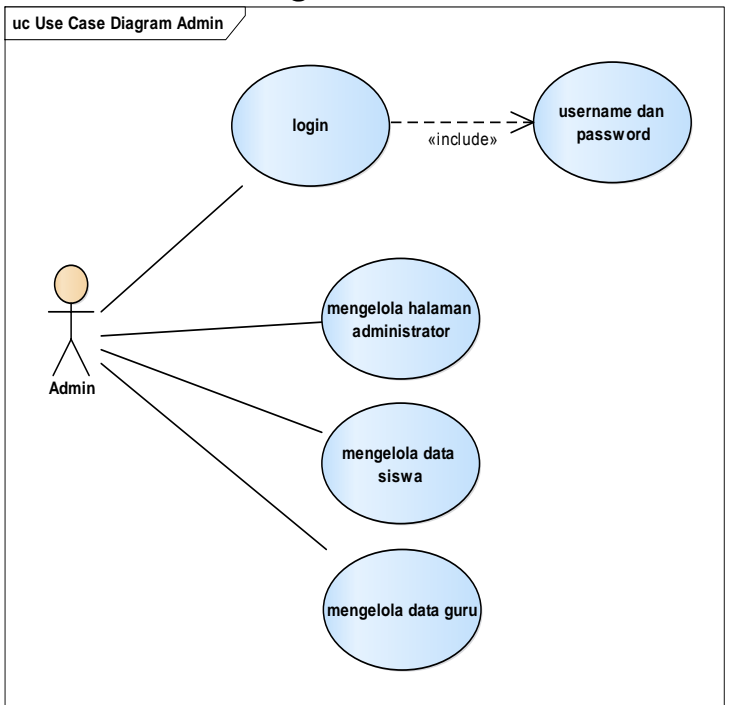

Gambar 1. Use case Admin

\section{Entity Relationship Diagram}

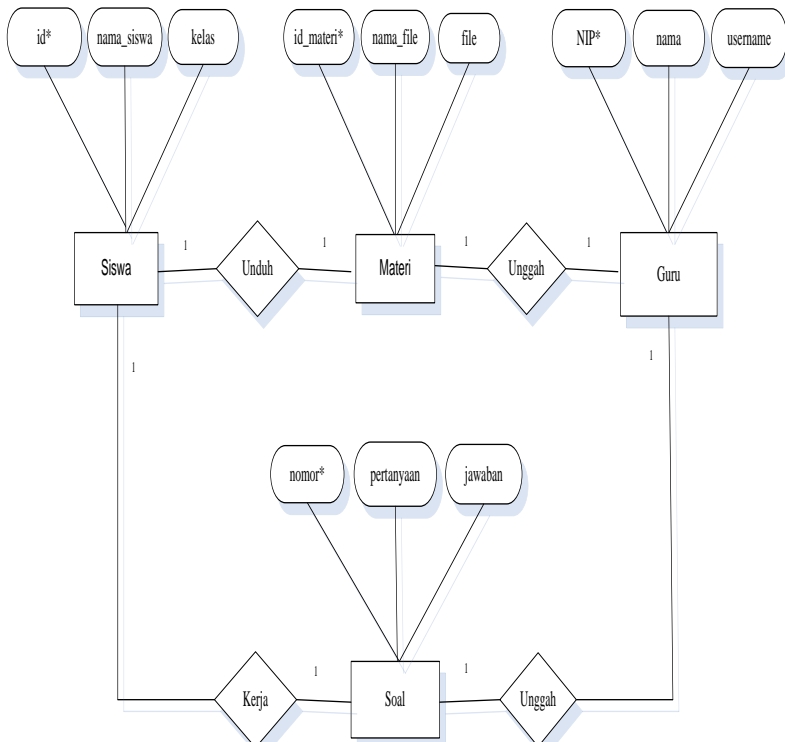

Gambar 3. Entity Relationship Diagram 


\section{Logical Record Structure}

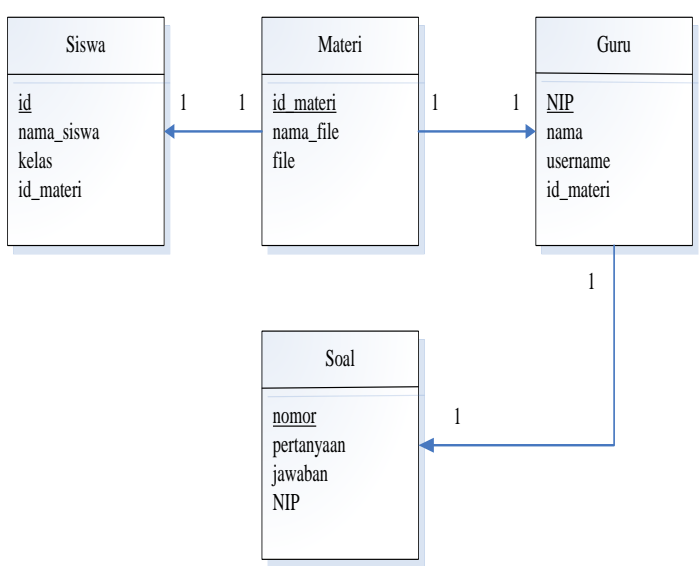

Gambar 4. Logical Record Structure

\section{Rancangan Tampilan Halaman} Utama

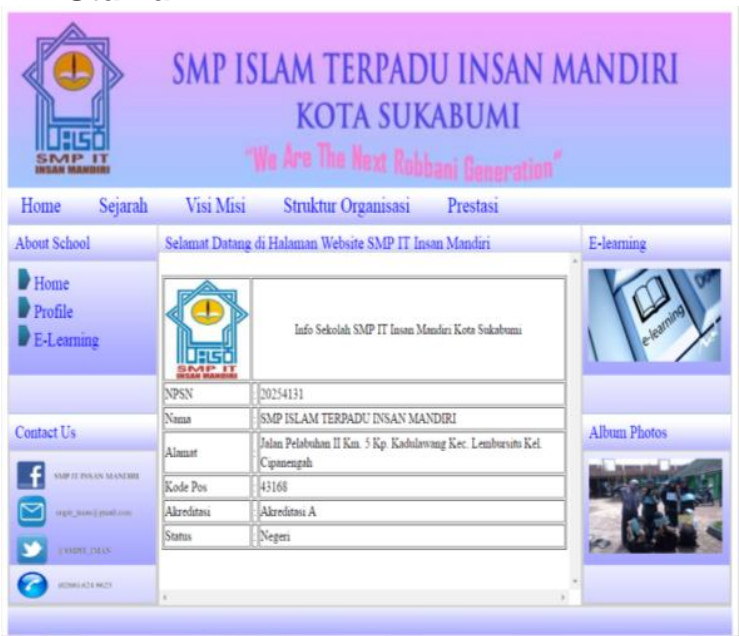

Gambar 5. Rancangan Tampilan Halaman Utama

\section{Rancangan Tampilan Index E-learning}

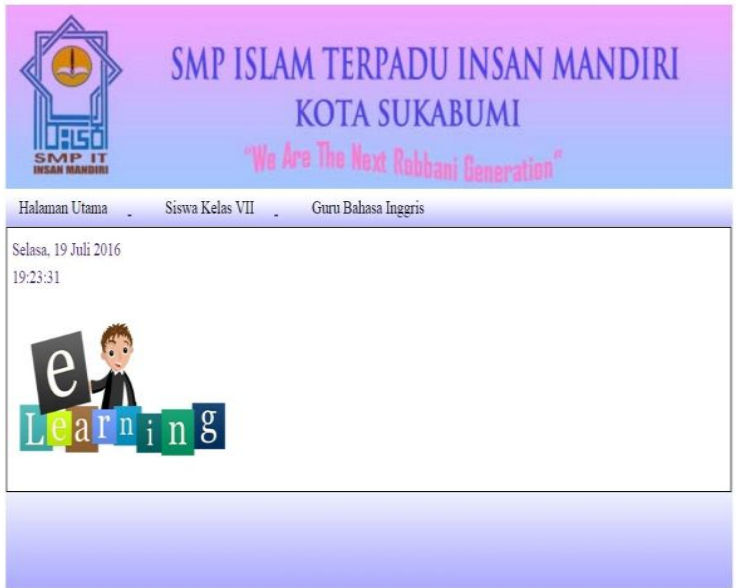

\section{Gambar 6. Rancangan Tampilan Index E- learning}

\section{Rancangan Tampilan Daftar E- learning}

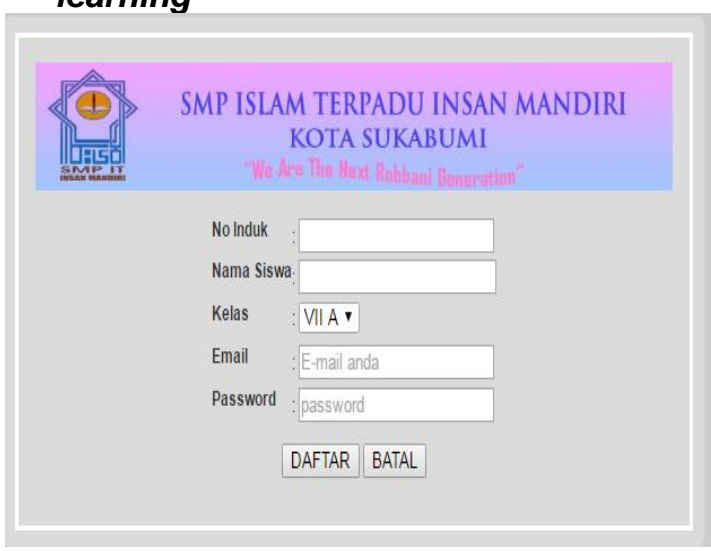

\section{Gambar 7. Rancangan Tampilan Daftar E-learning}

\section{Kesimpulan}

Dari hasil penelitian yang telah dilakukan d SMP Islam Terpadu Insan Mandiri Kota Sukabumi mengenai sistem pembelajaran yang ada khususnya untuk pelajaran Bahasa Inggris dirasakan kurang cukup efektif dalam meningkatkan kemampuan siswa dalam belajar, maka dibuatlah inovasi baru sebagai penunjang sistem pembelajaran Bahasa Inggris dengan memanfaatkan teknologi internet, yaitu dengan adanya E-learning dengan harapan dapat meningkatkan kemampuan siswa dalam belajar Bahasa Inggris, mempermudah dalam memperoleh materi karena dapat diakses kapanpun dan dimanapun, serta dapat menambah pengetahuan siswa mengenai teknologi internet. 


\section{Referensi}

Ardiansyah, Ivan. 2013. Eksplorasi Pola Komunikasi dalam Diskusi Menggunakan Moddle pada Perkuliahan Simulasi Pembelajaran Kimia, Universitas Pendidikan Indonesia, Bandung-Indonesia.

Astika, Gusti. 2015. Globalisasi Bahasa Inggris: So What ?. Lingua Vol.12 No. 1, Maret 2015.

Sriwihajriyah, Nyiman dkk. 2012. Sistem Pembelajaran dengan E-learning Untuk Persiapan Ujian Nasional pada SMA PUSRI Palembang. Jurnal Sistem Informasi Vol.4 No. 1, April 2012.

Turino, dkk. 2009. E-learning Bahasa
Inggris Berbasis Web. ISSN: 14149999.Jurnal Teknologi Informasi. Vol.5 No.2, Oktober 2009.

Winarno dan Johan Setiawan. 2013. Penerapan Sistem E-learning pada Komunitas Pendidikan Sekolah Rumah (Home Schooling). Mei 2015.

Winarno, Edi dan Ali Zaki Smitdev Comunity. 2013. Buku Sakti Pemrograman PHP.Jakarta: PT. Elex Media Komputindo.

Yazdi, Mohammad. 2012. E-learning Sebagai Media Pembelajaran Interaktif Berbasis Teknologi Informasi. Jurnal IImiah Foristek Vol.2 No.1, Maret 2012. 